\title{
Penerapan Autoregressive Integrated Moving Average (ARIMA) Pada Peramalan Produksi Kedelai di Sumatera Utara
}

\author{
Rita Herawaty Br Bangun* \\ Fungsional Statistisi Badan Pusat Statistik (BPS) Provinsi Sumatera Utara \\ *Email: rbangun62@gmail.com
}

\begin{abstract}
Abstrak
Kajian ini bertujuan untuk meramalkan produksi kedelai di Sumatera Utara tahun 2016-2019. Metode yang digunakan dalam penelitian ini adalah Metode Autoregressive Integrated Moving Average (ARIMA). Data deret waktu (time series) yang digunakan pada kajian ini adalah data produksi kedelai Provinsi Sumatera Utara tahun 2005-2015. Penggunaan model ARIMA dalam peramalan produksi kedelai Sumatera Utara menggunakan tiga tahapan analisis yaitu, pertama adalah identifikasi struktur model; kedua, estimasi dan kalibrasi model, dan terakhir adalah pengujian dan validasi model. Perangkat lunak yang digunakan sebagai alat bantu analisis model ARIMA ini adalah Minitab 18. Hasil kajian menunjukkan bahwa model yang terbaik digunakan untuk peramalan produksi kedelai adalah model $(0,1,1)$. Penerapan model arima pada produksi kedelai Sumatera Utara untuk 4 tahun berikutnya mengalami penurunan.
\end{abstract}

\section{Kata kunci : ARIMA; deret waktu; kedelai; ramalan}

\begin{abstract}
The study aims to forecast of soybean production in Province of Sumatera Utara about 2016-2019. Method of ARIMA (Autoregressive Integrated Moving Average) used to forecast of soybean production. Time series data were used on this study obtained from soybean production data in Province of Sumatera Utara about 2005-2015. This method consist three steps, firstly, model structure identification; second, model estimation and calibration; the last, model testing and validation, respectively. ARIMA model analyzed by Minitab 18 software as a tool. The result of study shows that the best of model used for forecasting soybean production is ARIMA model $(0,1,1)$. Application of the ARIMA model for forecasting four years later soybean production in Sumatera Utara will be decrease.
\end{abstract}

Keywords: ARIMA; time series,; soybean; forecasting.

\section{PENDAHULUAN}

Salah satu teknik peramalan yang saat ini berkembang adalah dengan menggunakan time series analysis (analisis deret waktu). Deret waktu didefinisikan sebagai serangkaian nilainilai variabel yang disusun berdasarkan waktu. Lebih lanjut, analisis deret waktu didefinisikan sebagai pola pergerakan nilai-nilai variabel tersebut pada suatu interval waktu (minggu, bulan, atau tahun) yang teratur (Mehrmolaei dan Keyvanpour, 2016). Sena dan Nagwani (2015) mendefinisikan analisis deret waktu sebagai analisis ramalan nilai masa depan berdasarkan nilai variabel dependen waktu yang telah diobservasi sebelumnya. Autoregressive integrated moving average (ARIMA) merupakan salah satu teknik analisis derat waktu yang banyak digunakan untuk peramalan data masa depan. Model ARIMA secara penuh mengabaikan independen variabel dalam membuat peramalan. ARIMA menggunakan nilai masa lalu dan sekarang dari variabel dependen untuk menghasilkan peramalan jangka pendek yang akurat. ARIMA cocok jika observasi dari deret 
waktu secara statistik berhubungan satu sama lain (dependent). ARIMA juga dapat dikombinasikan dengan menggunakan artificial neural network untuk mendapatkan hasil yang lebih komprehensif dan validitasnya lebih baik (Hirata et al., 2015).

Beberapa peneliti menggunakan model ARIMA untuk meramalkan kondisi masa depan seperti yang dilakukan oleh Sena dan Nagwani (2015) yang melakukan analisis deret waktu dengan menggunakan model ARIMA untuk meramal pendapatan perkapita sebagai alat untuk pengambilan kebijakan dan perencanaan masa depan sebuah negara. Kharista et al., (2015) juga menggunakan model ARIMA untuk memprediksi jumlah wisatawan asing yang berkunjung ke Indonesia. Penerapan ARIMA dalam bidang pertanian telah banyak dilakukan dalam rangka untuk memprediksi hasil produksi komoditas pertanian seperti yang telah dilakukan oleh Xingmei, et al., (2015) dalam meramal hasil produksi padi di Provinsi Jilin China. Haiyan dan Tao, (2015) melakukan analisis dengan menggunakan model ARIMA untuk mendesain dan mengimplementasikan produksi pertanian sebagai dasar dalam rangka memaksimalkan informasi pasar.

Kedelai sebagai salah satu komoditas penting di Indonesia bahkan di dunia telah banyak dijadikan objek penelitian yang bertujuan untuk melihat perkembangan produksi, mengingat sebagian besar kedelai dijadikan sebagai bahan pangan. Sebelumnya, Muslim (2014) melakukan peramalan harga paritas kedelai (Glicine max) dengan membandingkan metode ARMA (autoregressive-moving avarage) dan ANSIF (Adaptive Neuro-Fuzzy Inference System) dengan menyimpulkan bahwa kedua metode tersebut dapat dijadikan dasar yang kuat dalam peramalan harga kedelai. Komalasari (2008) juga melakukan peramalan harga kedelai dari segi permintaan dan pernawaran dengan menggunakan deret waktu winters multiplikatif dengan hasil penelitian yang mengindikasikan adanya defisit kedelai pada tahun 2009 dan 2010. Komalasari (2008) dan Muslim (2014) belum melakukan ramalan produksi kedelai, tetapi hanya melakukan penelitian mengenai harga kedelai yang berpengaruh terhadap produksi dan konsumsi. Hal inilah yang mendorong penulis untuk mencoba melakukan peramalan produksi kedelai sebagai komoditas penting di Indonesia. Kajian ini menitikberatkan pada penerapan ARIMA untuk meramal produksi kedelai di Provinsi Sumatera Utara. Peramalan produksi ini akan memberikan manfaat terhadap pengambilan kebijakan pemerintah Provinsi Sumatera Utara dalam pengembangan kedelai. Sampai dengan saat ini, produksi kedelai di Sumatera Utara belum menunjukkan hasil yang menggembirakan, sehingga kedelai di Sumatera Utara belum dapat dikategorikan sebagai komoditas pangan andalan. Untuk itu perlu dilakukan analisis pola ketersediaan kedelai Sumatera Utara sebagai dasar pengambilan kebijakan dalam pengembangan budidaya kedelai untuk mendukung program ketahanan pangan. Tujuan kajian ini adalah untuk memprediksi/meramal produksi kedelai Sumatera Utara menggunakan analisis 
deret wakatu (time series analysis) dengan model ARIMA.

\section{METODE PENELITIAN}

Jenis data yang digunakan dalam penelitian ini adalah data sekunder yang bersumber dari Dinas Tanaman Pangan dan Hortikultura Provinsi Sumatera Utara dan Badan Pusat Statistik Sumatera Utara. Data deret waktu yang digunakan adalah data produksi kedelai dari tahun 2005-2015. Data tersebut disampaikan pada Tabel 1.

Tabel 1. Data deret waktu produksi kedelai Provinsi Sumatera Utara.

\begin{tabular}{cccc}
\hline \multirow{2}{*}{ Tahun } & \multicolumn{3}{c}{ Produksi Kedelai (Ton) } \\
\cline { 2 - 4 } & $\begin{array}{c}\text { Januari- } \\
\text { April }\end{array}$ & $\begin{array}{c}\text { Mei- } \\
\text { Agustus }\end{array}$ & $\begin{array}{c}\text { September- } \\
\text { Desember }\end{array}$ \\
\hline 2005 & 7.481 & 4504 & 3808 \\
2006 & 2.808 & 2739 & 1495 \\
2007 & 1.532 & 1406 & 1407 \\
2008 & 4.630 & 3814 & 3203 \\
2009 & 6.643 & 5759 & 1804 \\
2010 & 3.258 & 4312 & 1869 \\
2011 & 3.533 & 3402 & 4491 \\
2012 & 1.654 & 2.656 & 1109 \\
2013 & 1.787 & 768 & 674 \\
2014 & 1.901 & 1.202 & 2602 \\
2015 & 2.590 & 1.404 & 2555 \\
\hline
\end{tabular}

Sumber data : BPS Provinsi Sumatera Utara

Penelitian ini menggunakan metode analisis deskriptif dan kuantitatif. Metode analisis deskriptif digunakan untuk menjelaskan dan menggambarkan produksi kedelai secara umum. Analisis deskriptif menggunakan metode pertumbuhan dengan tujuan untuk menganalisis apakah produksi kedelai Provinsi Sumatera Utara mengalami kenaikan atau penurunan. Persamaan penentuan analisis pertumbuhan dinyatakan dalam persamaan matematika (1).
$\mathrm{P}_{\mathrm{t}}=\mathrm{P}_{0}(1+\mathrm{r})^{\mathrm{n}}$

Analisis kuantitatif digunakan untuk meramalkan produksi kedelai pada tahun-tahun selanjutnya. Analisis kuantitatif menggunakan model ARIMA dijelaskan secara lengkap pada metode selanjutnya. Autoregresif Integrated Moving Average (ARIMA)sering juga disebut metode runtun waktu BoxJenkins yang menggunakan data deret waktu (Hirata et al., 2015; Sena dan Nagwani, 2015). Untuk peramalan dan prediksi jangka pendek, ARIMA mempunyai validitas dan ketepatan yang sangat baik, namun kekurangan ARIMA adalah tidak cocok untuk peramalan jangka panjang karena validitasnya kurang baik dan cenderung datar (flat) dan konstan (BPS, 2012).

Model ARIMA dibagi ke dalam 3 kelompok yaitu model model autoregressive (AR), moving average (MA), dan model campuran ARIMA (autoregressive moving average) yang mempunyai karakteristik dari dua model pertama (Sena dan Nagwani, 2015).

Pertama, model Autoregressive Model (AR) yang merupakan model autoregressive mendasarkan pada asumsi data pada periode sekarang dipengaruhi oleh data periode sebelumnya. Bentuk umum model matematika autoregressive dengan ordo $p(\operatorname{AR}(p))$ atau model ARIMA $(p, 0,0)$ dinyatakan dalam persamaan matematika (2).

$X_{t}=\phi_{1} X_{t-1}+\phi_{2} X_{t-2}+\ldots .+\phi_{1} X_{t-p}+\varepsilon t$

Dimana,

$X_{t} \quad$ : data pada periode ke-t

$\phi_{p} \quad$ : parameter autoregressive ke-p

$\varepsilon t \quad$ : nilai kesalahan pada saat $\mathrm{t}$, 
Kedua, model moving average

(MA) yang merupakan bentuk umum model moving average ordo $q(\mathrm{MA}(q))$ atau ARIMA $(0,0, q)$ dinyatakan dalam persamaan matematika (3).

$X_{t}=\varepsilon_{t}+\theta_{1} \varepsilon_{t-1}+\theta_{2} \varepsilon_{t-2 \ldots-}-\theta_{q} \varepsilon_{t-q}$

Dimana,

$X_{t} \quad$ : data pada periode ke-t

$\theta_{q} \quad$ : parameter moving average

$\varepsilon_{t-q} \quad$ : nilai kesalahan pada saat t-q

Ketiga, model autoregressive moving average (campuran) terdiri dari dua proses yang berbeda yaitu proses ARMA dan proses ARIMA. Model umum untuk proses ARMA adalah campuran dari ordo $p(\mathrm{AR}(\mathrm{p}))$ dan moving avarage ordo q (MA(q)) murni yang dinyatakan dalam persamaan matematika (4).

$$
\begin{aligned}
& X_{t}=\phi_{1} X_{t-1}+\phi_{2} X_{t-2}+\ldots+\phi_{p} X_{t-p}+\varepsilon_{t}-\theta_{1} \varepsilon(t-1)- \\
& \theta_{2} \varepsilon(t-2)-\ldots-\theta_{q} \mathcal{\varepsilon}(t-q) .
\end{aligned}
$$

Dimana,

$X_{t} \quad$ : data pada periode ke-t

$\phi_{p} \quad$ : parameter autoregressive ke-p

$\theta_{q} \quad$ : parameter moving average

$\varepsilon_{t} \quad$ : nilai kesalahan pada saat $\mathrm{t}$,

Sedangkan untuk model campuran proses ARIMA hampir sama seperti model ARMA, hanya saja model ARIMA didasarkan pada asumsi data pada periode sekarang yang dipengaruhi oleh data periode sebelumnya dan nilai residual data periode sebelumnya. Jika kondisi data non-stasioneritas ditambahkan pada campuran proses ARMA, maka model umum ARIMA $(p, d, q)$ terpenuhi. Persamaan untuk kasus sederhana ARIMA $(1,1,1)$ dinyatakan dalam persamaan matematika (5).

$\left(1-\phi_{1} B\right) X_{t}=\mu^{\prime}+\left(1-\theta_{1} B\right) e$
AR(1) MA(1)

Model ARIMA box-jenkins terdiri dari tiga tahapan, yaitu tahap identifikasi struktur model, tahap estimasi paramater dan kalibrasi, dan tahap pengujian dan validasi model (Sena dan Nagwani, 2015).

Tahap pertama yang dilakukan adalah identifikasi struktur model dengan menentukan kestasioneran data. Data yang stasioner dapat juga disebut sebagai data yang tidak mengandung trend. Sena dan Nagwani (2015) menyatakan bahwa kestasioneran data dapat dilihat dari uji Augmented Dicky Fuller (ADF) melalui pengamatan pola $\mathrm{ACF}$ (auto-correlation function) dan PACF (partial auto-correlation function). ACF dilakukan untu mengukur korelasi antara suatu variabel series dengan variabel series yang lain pada beberapa lag sebelumnya. Sementara itu, PACF untuk mengukur tambahan korelasi antara suatu series $Y$ dan nilai lag dari series tersebut yang tidak memperhitungkan lag dari series yang lebih rendah (Muslim, 2014). Data dengan rata-ratanya tidak stasioner dapat ditransformasi (distasionerkan) dengan metode pembedaan atau differencing, menghitung perubahan atau selisih nilai observasi. Jika belum stasioner maka perlu dilakukan differencing sesuai dengan direfensiasi derajat berapa data tersebut mencapai kestasioneran (first order diffrencing, second order diffrencing dan seterusnya) Selanjutnya, tahap kedua adalah melakukan estimasi dan kalibrasi model yang terdiri dari dua cara mendasar untuk melakukan estimasi model, yaitu (BPS, 2012): 
1. Cara coba-coba (trial and error), pengujian terhadap beberapa nilai yang berbeda dan memilih diantara nilai-nilai tersebut yang memiliki jumlah kuadrat nilai sisa (galat) (sum of squared residuals) yang minimum.

2. Perbaikan secara iteratif (pengulangan), Memilih nilai taksiran awal dan membiarkan program komputer untuk memperhalus penaksiran tersebut secara iteratif (berulang).

Tahapan terakhir adalah pengujian dan validasi model terbaik yang dilakukan dengan syarat model yang diperoleh dapat dikatakan baik jika nilai error-nya bersifat random, artinya sudah tidak mempunyai pola tertentu. Tahapan ini dilakukan uji diagnostik dalam upaya untuk memastikan apakah model yang diestimasi sudah baik atau belum. Untuk menentukan model yang terbaik dapat digunakan standard error estimasi yang dinyatakan dalam persamaan matematika (6).

$S=\left\lfloor\left.\frac{S S E}{n-n_{p}}\right|^{1 / 2}=\left[\frac{\sum_{t=1}^{n}\left(Y_{t}-\hat{\mathrm{y}}_{t}\right)^{2}}{n-n_{p}}\right]^{1 / 2}\right.$

Dimana,

SSE : standard error

$\mathrm{Y}_{\mathrm{t}} \quad$ : nilai sebenarnya waktu ke-t

$\hat{Y}_{t} \quad$ :nilai dugaan pada waktu ke-t

Model dikatakan terbaik jika model tersebut memiliki nilai standard error estimate (S) yang paling kecil. Penerapan model ARIMA terbaik akan digunakan untuk meramal produksi kedelai sumatera Utara pada 4 (empat) tahun medatang yaitu tahun 2016-2019. Perangkat lunak yang digunakan dalam membantu menganalisis model ARIMA adalah Minitab versi 18.

\section{HASIL DAN PEMBAHASAN}

Kajian ini akan membahas mengenai peramalan produksi kedelai di Provinsi Sumatera Utara dengan menggunakan data time series produksi kedelai antara tahun 2005-2015. Model ARIMA diimplementasikan untuk meramal dan memprediksi produksi kedelai di masa yang akan datang. Seluruh data diambil dari hasil survey pertanian dari Dinas Tanaman Pangan dan Hortikultura Provinsi Sumatera Utara yang dipublikasikan oleh Badan Pusat Statistik Provinsi Sumatera Utara dalam Statitistik Tanaman Padi dan Palawija Sumatera Utara Tahun 2015 (BPS,2016).

1. Produksi kedelai Sumatera Utara 2005-2015

Produksi kedelai selama tahun 2005-2015 di Sumatera Utara cenderung mengalami perlambatan pertumbuhan (Gambar 2), meskipun grafik tersebut menunjukkan pola fluktuatif. Pola fluktuasi terjadi pada tahun 2005-2007 yang mengalami penurunan produksi dan dilanjutkan kenaikan produksi pada tahun 20072009. Tahun 2009-2015 secara umum mengalami penurunan produksi yang cukup signifikan. Sehingga, dalam analisis pertumbuhan produksi kedelai Provinsi Sumatera Utara selama satu dekade terakhir cenderung mengalami penurunan sebesar 8,34 persen per tahun. Hal ini menunjukkan bahwa produksi kedelai Provinsi Sumatera Utara perlu mendapatkan perhatian khusus oleh pemerintah daerah terkait dengan stabilitas pangan. Data faktual 
ini sesuai dengan hasil penelitian dan ramalan Maretha (2008), yang melakukan peramalan produksi dan konsumsi kedelai secara nasional pada tahun 2008 dengan menggunakan model ARIMA dan menyatakan bahwa pada tahun 2015 belum terwujud swasembada kedelai nasional karena masih mengalami defisit/kesenjangan antara produksi dan konsumsi sebesar $37,2 \%$.

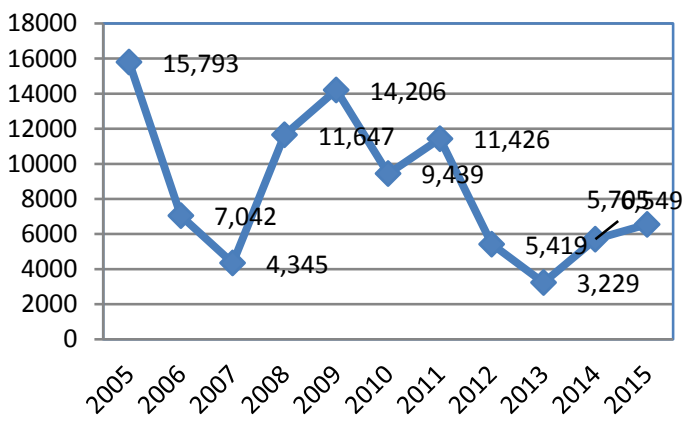

Gambar 2. Produksi Kedelai Sumatera Utara Tahun 2005-2015 (Ton)

\section{Analisis Autoregresif Integrated Moving Average (ARIMA)}

a. Tahap Identifikasi struktur model

Untuk melakukan analisis ARIMA, tahapan pertama yang harus dilakukan adalah identifikasi struktur model yang memungkinkan bisa terjadi. Persyaratan data yang akan dianalisis dengan ARIMA adalah data harus stasioner. Pada analisis plot series diketahui bahwa produksi kedelai menunjukkan data yang fluktuatif sehingga perlu dilakukan analisis pola trend untuk menentukan apakah data tersebut stasioner atau tidak (Gambar 3).

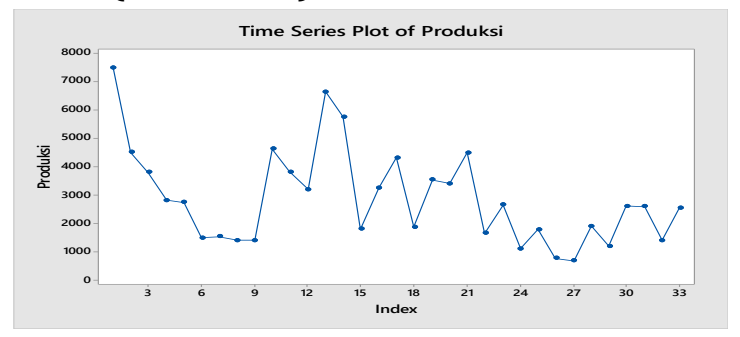

Gambar 3. Plot Series Produksi Kedelai Sumatera Utara

Untuk memperjelas kestasioneran data, analisis trend disajikan pada Gambar 4 yang menunjukkan bahwa produksi kedelai Sumatera Utara mengalami pola trend yang menurun, sehingga data produksi kedelai Sumatera Utara dapat dikatagorikan sebagai data yang tidak stasioner. Untuk mengatasi permasalahan data yang tidak stasioner tersebut, maka dilakukan diffrencing. Hasil differencing selanjutnya diuji kembali dengan uji autocorrelation function (ACF) dan partial autocorrelation function (PACF) seperti ditampilkan pada Gambar 5(a) dan 5(b).

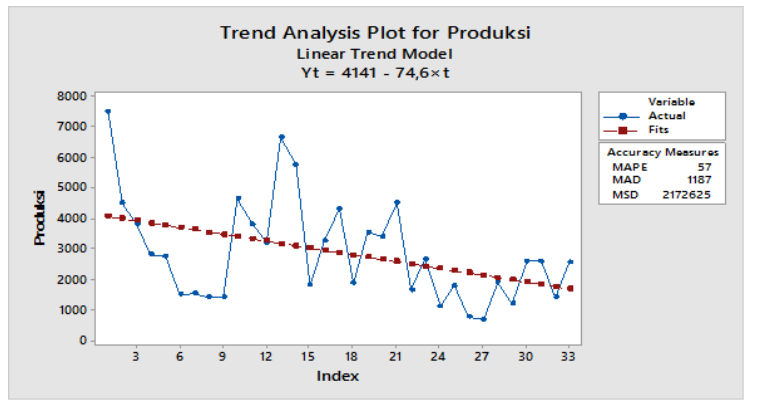

Gambar 4. Plot trend Produksi Kedelai Sumatera Utara

First order diffrencing dilakukan untuk melihat apakah data sudah stasioner atau belum dengan mengunakan uji ACF dan PACF. Gambar 5. Menunjukkan bahwa hasil diffrencing sudah menghasilkan data yang stationer, sehingga tidak perlu dilakukan kembali diffrencing selanjutnya (second order diffrencing). Hal ini ditunjukkan pada grafik plot pasangan ACF dan PACF dimana lag tidak keluar dari border/batas. Hasil uji ACF dan PACF menunjukkan bahwa data sudah stasioner pada mean dan varian 
sehingga dapat dilakukan tahapan selanjutnya yaitu estimasi dan kalibrasi model. Berdasarkan hasil identifikasi maka model sementara yang dihasilkan pada differencing adalah ARIMA $(0,1,1)$, $(1,1,0)$ dan $(1,1,1)$.

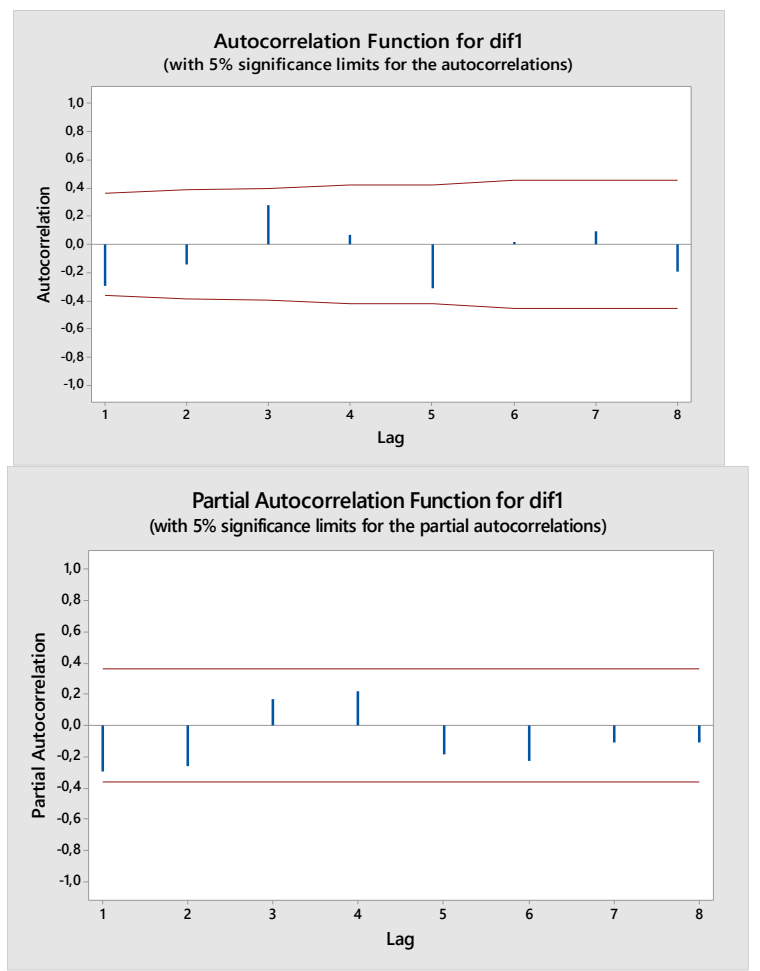

Gambar 5. (a) Grafik ACF dan (b) Grafik PACF setelah dilakukan differencing

b. Tahap Estimasi dan kalibrasi model
Setelah diperoleh model sementara, selanjutnya dilakukan estimasi parameter dari model sementara dan kalibrasi (checking) untuk menguji kesesuaian model tersebut dengan cara membandingkan nilai $p$-value dengan level toleransi $(\alpha)$. Hasil estimasi model ditampilkan pada Tabel 2. Level toleransi yang digunakan dalam kajian ini adalah 5\% dengan hipotesis yang digunakan adalah sebagai berikut:

$\mathrm{H}_{0}$ : Parameter tidak signifikan dalam model

$\mathrm{H}_{1}$ : Parameter signifikan dalam model

Kriteria penerimaan $\mathrm{H}_{0}$, jika $p$ value lebih besar dari $\alpha$ dan penolakan $\mathrm{H}_{0}, \quad$ jika $p$-value lebih kecil dari $\alpha$. Parameter dikatakan signifikan dalam model dengan kriteria penolakan $\mathrm{H}$. Estimasi dari ketiga model, hanya model ARIMA $(0,1,1)$ yang mempunyai $p$-value yang nilainya lebih kecil dari signifikansi $5 \%$, sehingga hanya model inilah yang dipilih menjadi model terbaik dalam peramalan produksi kedelai Sumatera Utara.

Tabel 2. Estimasi Produksi Kedelai dengan Model ARIMA (1,1,1), ARIMA $(1,1,10)$ dan ARIMA $(0,1,1)$

\begin{tabular}{lcrrrrc}
\hline \multicolumn{1}{c}{ Model/Parameter } & Variabel & Coef & SE Coef & T-Value & P-Value & MSE \\
\hline ARIMA (1,10) & AR (1) & $-0,339$ & 0,173 & $-1,96$ & 0,059 & 2477477 \\
Constant & & -190 & 278 & $-0,68$ & 0,500 & \\
\hline ARIMA (0,1,1) & MA (1) & 0,439 & 0,163 & 2,70 & 0,011 & 2328872 \\
Constant & & -122 & 152 & $-0,80$ & 0,430 & \\
\hline ARIMA (1,1,1) & AR (1) & $-0,010$ & 0,419 & $-0,02$ & 0,980 & 2409934 \\
& MA (1) & 0,430 & 0,379 & 1,14 & 0,265 & \\
Constant & & -123 & 156 & $-0,79$ & 0,437 & \\
\hline
\end{tabular}

Sumber: Data penelitian diolah, keterangan : Coef: koefisien, SE Coef :Standard Error koefisien, T-value : nilai T, P-value : nilai P dan MSE : measurment standard error.

Selain dari p-value, pemilihan model terbaik juga dapat dilakukan dari nilai MSE yang terkecil. Dalam Tabel 2 terlihat jelas bahwa nilai MSE terkecil adalah model ARIMA $(0,1,1)$. Andani (2008) menyatakan bahwa produksi 
pertanian terutama padi dalam model peramalannya menggunakan ARIMA secara signifkan memperlihatkan validasi yang sangat baik antara nilai ramalan dan nilai aktual. Peramalan produksi kedelai di Sumatera Utara juga menunjukkan validasi yang cukup baik.

c. Tahap pengujian dan validasi model

Setelah diketahui bahwa model terbaik adalah ARIMA $(0,1,1)$, maka perlu dilakukan verifikasi model. Untuk melakukan verifikasi model, maka dilakukan uji normalitas residual dan uji independensi (white noise). Pengujian kenormalan residual dilakukan dengan Uji Kolmogorov-Smirnov (Gambar 6) dengan menggunakan hipotesis sebagai berikut:

$\mathrm{H}_{0}$ : Residual berdistribusi normal

$\mathrm{H}_{1}$ : Residual tidak berdistribusi normal

Berdasarkan data olahan pada Tabel 2 pengujian kenormalan residual diketahui mempunyai nilai $\mathrm{p}$ ( $p$-value) melebihi nilai $\alpha$ (level toleransi) sebesar $5 \%$. Sehingga hipotesis $\mathrm{H}_{0}$ diterima yang berarti bahwa residual model telah terdistribusi secara normal.

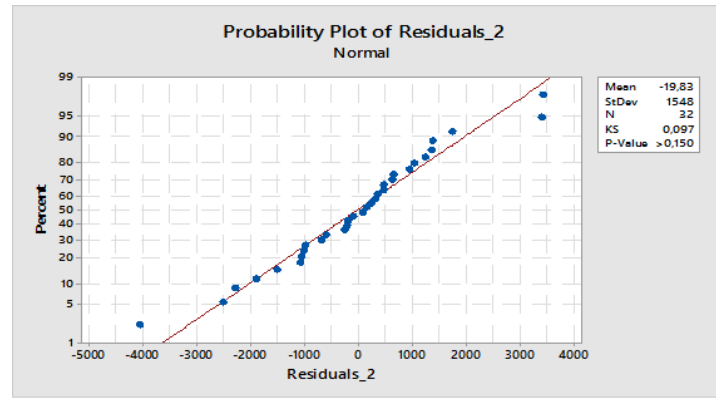

Gambar 7: Hasil pengujian residual model ARIMA $(0,1,1)$

Untuk pengujian independensi residual dan homogenitas dari residual (varians homogen) dilakukan menggunakan metode Ljung-Box dengan menggunakan hipotesis sebagai berikut:
$\mathrm{H}_{0}$ : Tidak ada korelasi residual antar lag $\mathrm{H}_{1}$ : Ada korelasi residual antar lag Berdasarkan nilai Chi-Square pada pengujian white noise model ARIMA $(0,1,1)$ beserta nilai statistik yang ditampilkan pada Tabel 3, memperlihatkan bahwa hasil uji homogenitas menunjukkan nilai $\mathrm{P}(p$ value) lebih besar dari nilai $\alpha$ (level toleransi) sebesar 5\%. Sehingga hipotesis $\mathrm{H}_{0}$ diterima yang berarti bahwa varian pada model telah homogen dan independen.

Tabel 3. Pengujian Ljung-Box ARIMA $(0,1,1)$

\begin{tabular}{cccc}
\hline Lag & $\begin{array}{c}\text { Chi- } \\
\text { Square }\end{array}$ & p-value & Kesimpulan \\
\hline 6 & 10,25 & 0,419 & White Noise \\
12 & 17,14 & 0,756 & White Noise \\
\hline
\end{tabular}

d. Aplikasi model ramalan produksi kedelai

Model terbaik yang diperoleh dari hasil analisis adalah model ARIMA $(0,1,1)$ akan digunakan untuk peramalan produksi kedelai Sumatera Utara pada tahun 2016-2019 yang dapat dituliskan dalam bentuk umum model persamaan matematika (7).

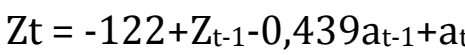

Berdasarkan model ARIMA $(0,1,1)$ tersebut, maka dapat dilakukan peramalan produksi kedelai untuk empat tahun mendatang. Hasil peramalan dapat dilihat pada Tabel 4 . 
Tabel 4. Peramalan Produksi Kedelai dengan ARIMA $(0,1,1)$

\begin{tabular}{lrrr}
\hline Periode & Forecast & Lower & Upper \\
\hline Jan- & 2014,4 & & 5006,1 \\
April & 6 & $-977,23$ & 4 \\
2016 & & - & \\
Mei- & 1892,7 & 1537,1 & 5322,6 \\
Agustu & 7 & 6 & 9 \\
s 2016 & & - & 5589,2 \\
Sept- & 1771,0 & 2047,1 & 7 \\
Des & 8 & 2 & \\
2016 & & - & 5819,8 \\
\hline Jan- & 1649,3 & 2521,0 & 5 \\
April & 8 & 8 & \\
2017 & & - & 6022,9 \\
Mei- & 1527,6 & 2967,5 & 1 \\
Agustu & 9 & 3 & \\
s 2017 & & - & 6204,0 \\
Sept- & 1406,0 & 3392,0 & 5 \\
Des & 0 & 4 & \\
2017 & & - & 6367,1 \\
\hline Jan- & 1284,3 & 3798,5 & 7 \\
April & 1 & 4 & \\
2018 & & - & 6515,1 \\
Mei- & 1162,6 & 4189,9 & 6 \\
Agustu & 2 & 1 & \\
s 2018 & & - & 6650,1 \\
Sept- & 1040,9 & 4568,3 & 9 \\
Des & 3 & 3 & \\
2018 & & - & 6773,9 \\
\hline Jan- & & 0 & 8 \\
April & 919,24 & 4935,5 & \\
2019 & & - & 6887,8 \\
Mei- & & 9 & 9 \\
Agustu & 797,55 & 5292,7 & \\
s 2019 & & - & 6993,0 \\
Sept- & 675,86 & 5 & 1 \\
Des & & & \\
2019 & & & \\
\hline & & & \\
\hline
\end{tabular}

Model ARIMA $(0,1,1)$ mempunyai koefisien -122 yang mempunyai arti bahwa jika produksi satu tahun sebelumnya ( $\mathrm{t}-1)$ meningkat satu ton, maka produksi pada tahun ke $\mathrm{t}$ akan bertambah sebesar 0,163 ton/tahun dikurangi dengan nilai konstanta sebesar 122 ton/tahun. Sehingga hal ini mengisyaratkan bahwa produksi kedelai setiap tahunnya akan berkurang sebesar 122 ton/tahun. Hal ini sesuai dengan analisis geometri pertumbuhan pada analisis deskripstif yang menyatakan bahwa terjadi pengurangan produksi kedelai sebesar 8,34 persen per tahun. Penurunan produksi kedelai di Sumatera Utara dalam beberapa tahun ke depan diduga karena terpengaruh oleh faktor-faktor produksi kedelai yang tidak mendukung seperti benih yang tidak unggul, ancaman hama penyakit tanaman, dan penggunaan pupuk yang tidak tepat serta intesifikasi pengolahan lahan pertanian yang tidak tepat (Wijayanti, 2014). Penurunan produksi kedelai ditunjukan pada pola trend peramalan produksi kedelai Sumatera Utara empat tahun kedepan (20162019) pada Gambar 8.

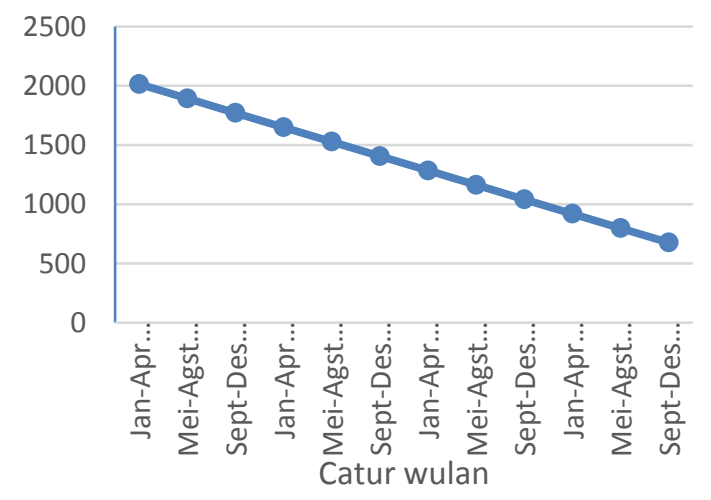

Gambar 8. Hasil ramalan menggunakan Model ARIMA produksi kedelai Sumatera Utara 4 tahun kedepan

Jika dibandingkan dengan penelitian Adillah (2014) yang melakukan peramalan produksi kedelai 
secara nasional tahun 2013-2020, maka kondisi Sumatera Utara berbeda dengan ramalan produksi secara nasional. Adillah (2014) menyatakan bahwa pertumbuhan produksi kedelai nasional sebesar 6,8 persen per tahun, meskipun terjadi defisit produksi dan konsumsi sebesar 0,98 persen per tahun.

\section{e. Strategi peningkatan produksi}

Hasil ramalan produksi kedelai Sumatera utara tahun 2016-2019 menunjukkan bahwa tingkat keberlanjutan hasil (product sustanability) sangat rendah. Sehingga, sistem produksi kedelai Sumatera Utara harus diperbaiki. Tastra et al., (2012) menyatakan bahwa faktor yang berpengaruh terhadap sistem produksi kedelai nasional adalah turunnya tarif impor keelai yang memicu harga kedelai di tingkat petani. Kondisi inilah yang menyebabkan kestabilan harga kedelai dalam negeri menjadi fluktuatif yang menyebabkan kurang berminatnya petani melakukan pengembangan budidaya kedelai di Sumatera Utara. Muslim (2010) menyatakan bahwa ketergantungan Indonesia pada kedelai impor mempengaruhi kemampuan swasembada kedelai, sehingga perhatian pemerintah mengenai perkembangan pertanian kedelai dinilai masih rendah.

Menurunnya produksi kedelai, baik data aktual dan data hasil ramalan dalam kajian ini dapat dijadikan referensi pemerintah daerah dalam mengambil kebijakan dalam pengembangan produksi kedelai di sumatera Utara. Kebijakan-kebijakan tersebut dapat diterapkan dalam berbagai pendekatan antara lain dalam bentuk insentif kepada petani kedelai, subsidi pupuk, antisipasi fluktuatif harga kedelai di tingkat petani dengan pembentukan kelembagaan ditingkat petani, dan juga penggunaan teknologi informasi sebagai sarana memantau fluktuatif harga kedelai juga perlu mendapatkan perhatian pemerintah. Tastra et al., (2012) merumuskan strategi peningkatan sistem produksi kedelai dalam beberapa langkah yaitu, penerapan subsidi harga yang adil dan wajar, pengembangan subsistem jabalsim (penyebaran varietas unggul) kedelai, perluasan areal, improvisasi inovasi teknologi terapan tanam kedelai dengan teknologi mekanis tepat guna, dan teknologi pengolahan hasil panen. Sedangkan Maretha (2008) merumuskan empat strategi untuk meningkatkan produksi kedelai dengan cara memberlakukan tarif impor kedelai lebih dari 20\%, meningkatkan kerja sama dan peran serta masyarakat dalam penelitian dan pengembangan kedelai, meningkatkan penyajian benih unggul, perbaikan genetis, dan teknologi budidaya, pascapanen dan pengolahan (diversivikasi produk), dan terakhir keamanan dan higienitas kedelai yang dikonsumsi msyarakat.

\section{SIMPULAN}

Kajian tentang penerapan ARIMA untuk peramalan produksi kedelai Sumatera Utara telah dilakukan. Hasil kajian menyimpulkan bahwa model ARIMA yang terbaik untuk peramalan produksi kedelai adalah ARIMA $(0,1,1)$. Perkiraan produksi kedelai pada subround Januari-April 2016 sebesar 2.014 ton, subround Mei-Agustus 2016 sebesar 1.892 ton dan subround September-Desember 2016 sebesar 
1.771 ton. Hasil kajian ini diharapkan dapat menjadi acuan pengambilan kebijakan oleh pemerintah dalam rangka peningkatan produksi kedelai indonesia, khususnya Sumatera Utara.

\section{DAFTAR PUSTAKA}

Adillah, R., 2014., Analisis produksi dan konsumsi kedelai nasional., Institut Pertanian Bogor., Bogor., Tesis.

Andani, A., 2008., Analisis prakiraan produksi dan konsumsi beras Indonesia., AGRISEP (8) 1: 1-18.

BPS., 2012., Analisis data deret berkala., modul diklat fungsional statistisi ahli., Badan Pusat Statistik., Jakarta.

BPS., 2016. Statistik tanaman padi dan palawija Sumatera Utara 2015. Badan Pusat Statistik Provinsi Sumatera Utara., Medan.

Hirata, T., Kuremoto, T., Obayashi, M., Mabu, S., dan Kobayashi, K., 2015., Time Series Prediction using DBN and ARIMA., International Conference on Computer Application Technologie (ICCAT): 24-29. DOI 10.1109/CCATS.2015.15.

Kharista, A., Permanasari, A.E., dan Hidayah, I., 2015., The Performance of GM $(1,1)$ and ARIMA for Forecasting of Foreign Tourists Visit to Indonesia., International Seminar on Intelligent Technology and Its Applications (ISITA): 33-37., DOI: 10.1109/ISITIA.2015.7219949.

Komalasari W.B. 2008. Prediksi Penawaran dan Permintaan Kedelai dengan Analisis Deret Waktu. Jurnal Informatika Pertanian Volume 17 No.2, 2008: 1195-1208.
Maretha, D. 2008., Peramalan Produksi dan Konsumsi Kedelai Nasional Serta Implikasinya Terhadap Strategi Pencapaian Swasembada Kedelai Nasional., Institut Pertanian Bogor., Bogor., Skripsi.

Mehrmolaei, S., dan Keyvanpour, M.R., 2016., Time series forecasting using improved ARIMA. Artificial Intelligence and Robotics (IRANOPEN): 92-97. DOI: 10.1109/RIOS.2016.7529496.

Muslim, A., 2014., Peramalan harga paritas kedelai model ANFIS. Widyariset. (17)1:13-24.

Sena, D., dan Nagwani, N.K., 2015., Application of Time Series Based Prediction Model to Forecast Per Capita Disposable Income., IEEE International Advance Computing Conference (IACC): 454-457., DOI: 10.1109/IADCC.2015.7154749.

Tastra, I.K., Ginting, E., dan Fatah, G.S.A., 2012., Menuju swasembada kedelai melalui penerapan kebijakan strategis., Iptek Tanaman Pertanian (7)1:47-57.

Wijayanti, C.D., 2014., Analisis Peramalan Produksi Kedelai dan Konsumsi serta Faktorfaktor yang Mempengaruhi Produksi dalam Pencapaian Swasembada Kedelai., Institut Pertanian Bogor., Bogor., Skripsi.

Xingmei, X., Liying, C., Jing, Z., dan Fengyan, S., 2015., Study and Application of Grain Yield Forecasting Model., 4th International Conference on Computer Science and Network Technology (ICCSNT):652-656. DOI:

10.1109/ICCSNT.2015.7490829 